\title{
46,XX ovotesticular disorder of sex development
}

INSERM

\section{Source}

INSERM. (1999). Orphanet: an online rare disease and orphan drug data base. $\underline{46, X X}$ ovotesticular disorder of sex development. ORPHA:2138

$46, X X$ ovotesticular disorder of sex development ( $46, X X$ ovotesticular DSD) is characterized by histologically confirmed testicular and ovarian tissue in an individual with a 46,XX karyotype. 